\title{
The Effectiveness of the Student Activity Sheet (SAS) on Teaching- Learning and Creativity (TLC) Model to Increase Creativity Competence
}

\author{
${ }^{*}$ Dwikoranto ${ }^{1}$, R Setiani ${ }^{2}$, B Widuroyekti ${ }^{3}$, S Tresnaningsih ${ }^{4}$, D Sambada ${ }^{4}$, T Setyowati ${ }^{4}$, A Rohman $^{5}$, B \\ T Harnoto 6 \\ ${ }_{1}^{1}$ Department of Physics, Faculty of Mathematics and Natural Science, Universitas Negeri Surabaya, Indonesia \\ 2Bhinneka PGRI University of Tulungagung, Indonesia \\ 3Open University UPBJJ-UT Semarang, Indonesia \\ ${ }^{4}$ Open University UPBJJ-UT Surabaya, Indonesia \\ 5STKIP Al Hikmah Surabaya, Indonesia \\ ${ }^{6}$ SMAN 1 Krembung Sidoarjo, Indonesia
}

\begin{tabular}{l} 
Article Info \\
\hline Article history: \\
Received July 30, 2020 \\
Revised December 26, 2020 \\
Accepted December 28, 2020 \\
Available Online December 29, \\
2020 \\
\hline
\end{tabular}

Keywords:

Competence

Creativity

Effectiveness

SAS

TLC

\begin{abstract}
The purpose of this study explains the effectiveness of the student activity sheet model to enhance scientific creativity and student learning outcomes and student responses to the learning process. The research design used pre-experimental with one group pretestposttest design. The study's subject was the student activity sheet (SAS) model and the implementation of primary teacher Education undergraduate students who programed a science introductory concept course during the 2019.1 registration at Open University. Data collected using test methods and questionnaires with product cognitive test instruments, cognitive process tests, scientific creativity tests and student questionnaire responses. Data analyzed by t-test and the proportions calculated. Normality test and homogeneity test are done before the t-test is applied. Increased creativity and student learning outcomes are calculated using normalized N-Gain. The results showed: 1) Improvement of students' scientific creativity after joining learning in the medium category. 2) Improving student learning outcomes after participating in learning in the good category. 3) Student responses to the learning process in the positive category. Based on the above, it can be concluded that the application of student activity sheet model used in learning activities to improve scientific creativity competency and student learning outcomes is effective.
\end{abstract}

\section{INTRODUCTION}

Experimental activities and quantitative measurements aim to identify basic laws governing natural phenomena and use them to develop theories that can predict experimental results, an intellectual culture that encourages fundamental creativity from important science and needs to be improved (Jewett \& Serway, 2008; Mukhopadhyay \& Sen, 2013). Teaching is not enough to master the core subject and be equipped with critical thinking, communication, collaboration, and creativity to accommodate the needs of century skills (Kellog et al., 2011).

Problem-solving is very much related to creativity. Students who have the right conception of the nature of learning science will use various approaches to study deeply and encourage the growth of creativity. Scientific creativity of some student-teacher candidates in terms of applying concepts, exploring ideas, designs and scientific products is still lacking (Suyidno et 
al., 2015; Mueller et al., 2012; Rietzscehl et al., 2010; Mukhopadhyay \& Sen, 2013). The Scientific Structure Creativity Model (SSCM) as a theoretical basis for measuring scientific creativity is complemented by seven items of scientific creativity tests (Hu \& Adey, 2010). They recommend that they be used as an empirical basis for researchers interested in scientific creativity and developing specific intervention programs to practice scientific creativity. Interventions that can be used to practice scientific creativity include Project-Based Laboratory Learning (Dwikoranto et al., 2019) Problem Based Learning (Suyidno, 2019; Ghorgiu et al., 2015), Learn to Think (Hu et al., 2013), Teaching, Learning and Creativity Models for Science (Rotteram, 2014), Project-based Science Creative Learning (SCL) (Wibowo \& Suhandi, 2013). The researchers recommend that lecturers should pay attention to the importance of feedback, application, scientific literacy for creativity (Moutinho et al., 2015; Ghorgiu et al., 2015; Rotteram 2014). The Teaching-Learning and Creativity (TLC) model exists to accommodate it and needs to be tested for its effectiveness in various study fields (Dwikoranto et al., 2019). TLC models with creativity indicators: unusual use, problem finding, product improvement, scientific imagination, science problem solving, science experiments, and product design. This model was developed in five phases: problem orientation, problem finding, problem-solving, advanced training, evaluation and follow-up (Suyidno et al., 2018; Demir \& Sahin, 2014; Ayas, M.B. \& Sak, U. 2014). The TLC for Science Model's core phase is the creativity phase; lecturers can train through the activities on the student activity sheet (SAS). Creativity assignments are given in SAS to expand the range of creative activities, so students can apply, produce, find, compare, connect, discover, imagine and plan.

Creativity can be seen as a creative process, creative person, creative product, and creative environment (Sudarma, 2012; Fryer, 2012; Torrance, 2013; Liu \& Lin, 2013). Creativity is the process of sensitivity to a problem, identifying difficulties, finding solutions by making guesses or formulating hypotheses, testing and re-testing hypotheses, modifying, and finally communicating the results (Torrance, 2013). The resulting creative solutions take new solutions or new ideas that show fluency, flexibility, originality, and detail in thinking. Lecturers should focus on the process of encouraging the development of student scientific creativity in order to produce creative work. Creative products result from creative thinking which is seen as something new (Nur, 2014; Dwikoranto et al., 2020).

The key factor in developing creativity is an atmosphere of free, open, democratic, and positive learning. Student Worksheets that accommodate this can be used to enhance creativity in science today. There is a significant positive relationship between achievement motivation and the ability to think creatively. It means that the higher the achievement motivation, the higher the ability to think creatively, and vice versa (Hu et al., 2013). Students are motivated during the learning process, help think flexibly, do not control excessively, collaborate with creative people (Santrock, 2009).

Science learning to practice scientific creativity involves the interaction of hypothesis generalization, experimental design, and evaluation of evidence (Mukhopadhyay \& Sen, 2013; Ayas \& Sak, 2014). Hypothesis generalization involves students formulating hypotheses derived from prior knowledge or experimental data, then verifying the rationality of the hypotheses to be investigated. Experimental design involves students in designing and carrying out appropriate experiments to prove or refute hypotheses. Evaluation of evidence is done by verifying the compatibility of the theory with the results of the investigation. It can be designed integrated into laboratory activities in the form of the Student Activity Sheet (SAS) (Dwikoranto et al., 2018).

Student Activity Sheet is one of the learning resources that can be developed by lecturers as facilitators in learning activities that can be designed and developed according to the conditions and situations of learning activities to be encountered and the objectives to be achieved (Astutik \& Prahani, 2018; Dwikoranto et al., 2018). SAS is one of the facilities to help facilitate learning 
activities that can form effective interactions between students and lecturers to improve student achievement (Rahardjanto et al., 2019).

The creativity assessment adapted the seven items of scientific creativity instrument from $\mathrm{Hu}$ and Adey in an essay test. Essay tests enable students to produce answers that meet the criteria of fluency, flexibility, originality, and elaboration that need to be tested in various courses (Eggen \& Kauchak, 2013). The development of students' scientific creativity will positively contribute to improving cognitive learning outcomes of products and processes, affective, and psychomotor.

Based on the preceding, the general formulation of the problem in this study is, "Is the student activity sheet model applied to enhance scientific creativity and student learning outcomes effective?". The formulation of this problem can be broken down into three research questions as follows.

1. How is the improvement of students' scientific creativity after participating in learning with student activity sheet model?

2. How to improve student learning outcomes after participating in learning with student activity sheet model?

3. How is the student's response to the learning process with the student activity sheet model?

Research Objectives explain the effectiveness of student activity sheet Model to enhance scientific creativity and student learning outcomes and student responses to the learning process with the student activity sheet model.

This research contributes: 1) For lecturers, student activity sheet model can be used as an alternative learning strategy to provide direct experience in increasing scientific creativity and student learning outcomes. 2) For students, student activity sheet model can experience direct experience in increasing scientific creativity and learning outcomes. 3) For institutions, as a study material to innovate learning and curriculum development that meets the demands of 21st-century competence. 4) For other researchers, student activity sheet model can be used as input and consideration in developing relevant and broader research.

\section{RESEARCH METHOD}

\section{Type of Research}

This type of research is pre-experimental design research to see the extent of the student activity sheet model's effectiveness in learning in class using one group pretest-posttest design (Sugiyono, 2010).

\section{Research Variables and Operational Definition Variables}

a. The effectiveness of student activity sheet model is that the use of SASs is expected to produce the desired results. SAS is said to be effective if it can increase scientific creativity and student learning outcomes, increase scientific creativity and student learning outcomes after learning better than before learning, students are active during the learning process and students' positive responses to the learning process.

b. Scientific Creativity is Creativity in learning that is emphasized on unusual use indicators, problem finding, product improvement, scientific imagination, science problem solving, science experiments, and product design. Scientific Creativity is measured before and after the learning process by completing items on the Scientific Creativity Test Sheet Instrument.

c. Student Learning Outcomes emphasized on cognitive and psychomotor learning outcomes. Student learning outcomes are measured before and after the learning process by completing items on the Product Cognitive Test Sheet Instrument, Process Cognitive Test Sheet Instrument, Psychomotor Test Sheet Instrument.

d. Student Response is the student's opinion on the student activity sheet Model used, scientific Creativity that is trained, the learning atmosphere, and how the tutor teaches by filling in the Student Response Instrument Sheet on the student activity sheet model. 


\section{Research Subjects}

The study's subject was the student activity sheet model and for the implementation of primary teacher Education undergraduate students who programed the basic science subject in the 2019.1 registration period at Open University.

\section{Data Collection Techniques}

Data on scientific creativity and learning outcomes were collected through tests before and after the learning process by working on the Product Cognitive Test Sheet Instrument, the Process Cognitive Test Sheet Instrument, the Scientific Creativity Test Sheet Instrument. Student response data is obtained by asking students to fill in the Student Response Questionnaire Sheet at the end of learning.

\section{Data Analysis Techniques}

\section{a. Scientific Creativity}

Scientific creativity is analyzed based on students' scores before and after learning using the student activity sheet model. The value of scientific creativity of students 'pretest and posttest results were analyzed with $\mathrm{N}$-gain to show the degree of increase in students' scientific creativity before and after learning with the student activity sheet model. The results of the Ngain calculation are then converted to the criteria in Table 1.

Table 1. Normalized Gain Criteria

\begin{tabular}{|c|c|}
\hline N-Gain Score & Normalized Gain \\
\hline $0.70<$ N-Gain & High \\
\hline $0.30 \leq$ N-Gain $\leq 0.70$ & Medium \\
\hline N-Gain $<0.30$ & Low \\
\hline & (Gronlund \& Linn, 1985)
\end{tabular}

The sensitivity index of an item is a measure of how well the item distinguishes students' ability before and after learning by using the student activity sheet model. An item is said to be sensitive to learning if $S \geq 0.30$.

1) Homogeneity Test

Homogeneity test aims to determine that the data obtained are homogeneous or not homogeneous. Test the homogeneity of the pretest, posttest data, using the Levene Test.

2) Normality Test

The normality test aims to find out that the data obtained has a normal or abnormal distribution. Normality test is performed for pretest, posttest data using the KolmogorovSmirnov test.

3) Differences in Scientific Creativity Before and After Using a model

The difference test is used to determine the significance of the model in enhancing scientific creativity by testing the difference in the average score of pretest and posttest of students who use the student activity sheet model. Statistical tests using Paired Sample t-test (Trihendradi, 2011).

\section{b. Student Learning Outcomes}

Student learning outcomes were analyzed based on scores obtained by students before and after learning using the student activity sheet model. The learning outcomes of students' pretest and posttest were analyzed with $\mathrm{N}$-gain to show the degree of influence of the increase in student learning outcomes before and after learning with student activity sheet model. The n-gain calculation results are then converted to the criteria in Table 1.

\section{c. Student response}

Student response questionnaire was used to find out students' opinions on student activity sheet model along with tools developed, scientific creativity, learning atmosphere, and the way 
the lecturer taught. Student responses were analyzed descriptively qualitatively with Percentage.

RESULTS AND DISCUSSION

1. Improvement of students' scientific creativity after participating in learning with student activity sheet model can be observed in Table 2 below.

Table 2. Results of Student Creativity Analysis

\begin{tabular}{|c|c|c|c|c|c|c|c|}
\hline \multirow[b]{2}{*}{ Indicator } & \multirow[b]{2}{*}{ Information } & \multicolumn{3}{|c|}{ Pretest } & \multicolumn{3}{|c|}{ Posttest } \\
\hline & & $\Sigma \mathrm{N}$ & $\begin{array}{c}\text { Completeness } \\
\text { Indicator }\end{array}$ & $\overline{\mathrm{x}}$ & $\Sigma \mathrm{N}$ & $\begin{array}{c}\text { Completeness } \\
\text { Indicator }\end{array}$ & $\overline{\mathrm{x}}$ \\
\hline \multirow{2}{*}{ Unusual use } & complete & 10 & \multirow{2}{*}{33.33} & \multirow{2}{*}{50.40} & 27 & \multirow{2}{*}{90.00} & \multirow{2}{*}{90.60} \\
\hline & Not complete & 20 & & & 3 & & \\
\hline \multirow{2}{*}{ Problem finding } & complete & 8 & \multirow{2}{*}{26.67} & \multirow{2}{*}{48.60} & 27 & \multirow{2}{*}{90.00} & \multirow{2}{*}{88.60} \\
\hline & Not complete & 22 & & & 3 & & \\
\hline \multirow{2}{*}{$\begin{array}{l}\text { Product } \\
\text { improvement }\end{array}$} & complete & 10 & \multirow{2}{*}{33.33} & \multirow{2}{*}{48.50} & 26 & \multirow{2}{*}{86.67} & \multirow{2}{*}{88.50} \\
\hline & Not complete & 20 & & & 4 & & \\
\hline \multirow{2}{*}{$\begin{array}{l}\text { Scientific } \\
\text { imagination }\end{array}$} & complete & 10 & \multirow{2}{*}{33.33} & \multirow{2}{*}{44.12} & 26 & \multirow{2}{*}{86.67} & \multirow{2}{*}{89.12} \\
\hline & Not complete & 20 & & & 4 & & \\
\hline \multirow{2}{*}{$\begin{array}{l}\text { Science problem } \\
\text { solving }\end{array}$} & complete & 14 & \multirow{2}{*}{46.70} & \multirow{2}{*}{62.50} & 25 & \multirow{2}{*}{83.33} & \multirow{2}{*}{84.50} \\
\hline & Not complete & 16 & & & 5 & & \\
\hline \multirow{2}{*}{ Science experiment } & complete & 9 & \multirow{2}{*}{30.00} & \multirow{2}{*}{26.67} & 26 & \multirow{2}{*}{86.67} & \multirow{2}{*}{80.83} \\
\hline & Not complete & 21 & & & 4 & & \\
\hline \multirow{2}{*}{ Product design } & complete & 11 & \multirow{2}{*}{36.67} & \multirow{2}{*}{50.83} & 24 & 800 & 7215 \\
\hline & Not complete & 19 & & & 6 & 80.00 & $/ 2.13$ \\
\hline
\end{tabular}

Note: $\overline{\mathrm{X}}=$ Average Score, $\Sigma \mathrm{N}=$ Sum of Student.

Based on Table 2. Before applying the TLC model of SAS, the number of students who completed the indicators and those who did not complete, of the seven indicators determined, there were still many indicators that were incomplete. After the face-to-face meeting the opposite occurs. For all indicators at the time of the final test all indicate complete indicators. This means that the application of the SAS model of the TLC created has indeed led to this. This reinforces and is in line with the results of research conducted by previous researchers that motivation can be formed and enhanced by interventions in learning (Jamal, 2015; Dwikoranto et al, 2019; Suyidno et al, 2015; Hu \& Adey, 2010).

Increased creativity in unusual use indicators to product design by students related to student activity sheet models the results can be observed in the following Table 3.

Table 3. Value of N-Gain and Sensitivity of Creativity Items

\begin{tabular}{|c|l|c|l|c|l|}
\hline \multirow{2}{*}{ No } & \multirow{2}{*}{ Indicator } & \multicolumn{2}{c|}{ N-Gain } & \multicolumn{2}{c|}{ Sensitivity } \\
\cline { 3 - 6 } & & Coeficient & Information & Coeficient & Information \\
\hline 1 & Unusual use & 0.81 & High & 0.48 & Sensitive \\
\hline 2 & Problem finding & 0.78 & High & 0.64 & Sensitive \\
\hline 3 & Product improvement & 0.78 & High & 0.67 & Sensitive \\
\hline 4 & Scientific imagination & 0.81 & High & 0.54 & Sensitive \\
\hline 5 & Science problem solving & 0.59 & Medium & 0.38 & Sensitive \\
\hline 6 & Science experiment & 0.74 & High & 0.35 & Sensitive \\
\hline 7 & Product design & 0.43 & Medium & 0.12 & Not Sensitive \\
\hline
\end{tabular}


Of the seven indicators, as many as five indicators increased in the high category (i.e. indicators 1, 2, 3, 4, 6; unusual use, problem finding, product improvement, scientific imagination, science experiment. While the two indicators namely science problem solving and product design and increase in moderate criteria, this provides an opportunity for further research for other researchers to do so, this high increase is due to proper conditioning in SAS designed with content that fits the indicator (Nur, 2014; Dwikoranto et al., 2018; McCarty, C, 2010). In science indicator, problem-solving students still need scaffolding to achieve high $\mathrm{N}$ gain. Product design requires individual experience and repetitive activities in the learning process.

Similarly, in terms of the sensitivity of the items designed, the same thing is obtained: unusual use, problem finding, product improvement, scientific imagination, problem-solving science, a science experiment in the sensitive category. Simultaneously, product design indicators in the category are not sensitive (Trihendradi, 2011). The sensitivity index of the items made by referring to the seven indicators above can distinguish students' ability before and after learning by using the student activity sheet model. An item is sensitive to learning if the value of $S \geq 0.30$ and these criteria are met for the 6 item indicators.

\section{Improving Student Learning Outcomes After Following Learning With student activity sheet model}

Student learning outcomes are netted with 6 test instruments for cognitive learning outcomes of product 1 , cognitive products 2 , cognitive process 1 , cognitive process 2 , psychomotor 1 , and psychomotor 2 which are integrated with the process of learning activities in the real class the results can be seen in Table 4 below.

Table 4. Analysis Results of Learning Outcomes Tests

\begin{tabular}{|c|c|c|c|c|c|c|c|}
\hline \multirow{2}{*}{$\begin{array}{c}\text { Learning Outcomes } \\
\text { Test }\end{array}$} & \multirow{2}{*}{ Information } & \multicolumn{3}{|c|}{ Pretest } & \multicolumn{3}{|c|}{ Posttest } \\
\hline & & $\Sigma \mathrm{N}$ & Complete & $\overline{\mathrm{X}}$ & $\Sigma \mathrm{N}$ & Complete & $\overline{\mathrm{X}}$ \\
\hline \multirow{2}{*}{ Cognitive Products1 } & Complete & 4 & \multirow{2}{*}{13.33} & \multirow{2}{*}{49.17} & 28 & \multirow{2}{*}{93.33} & \multirow{2}{*}{86.67} \\
\hline & Not Complete & 26 & & & 2 & & \\
\hline \multirow{2}{*}{ Cognitive Products 2} & Complete & 6 & \multirow{2}{*}{20.00} & \multirow{2}{*}{34.17} & 29 & \multirow{2}{*}{96.67} & \multirow{2}{*}{88.33} \\
\hline & Not Complete & 24 & & & 1 & & \\
\hline \multirow{2}{*}{ Cognitive Process1 } & Complete & 4 & \multirow{2}{*}{13.3} & \multirow{2}{*}{22.50} & 28 & \multirow{2}{*}{93.33} & \multirow{2}{*}{80.00} \\
\hline & Not Complete & 26 & & & 2 & & \\
\hline \multirow{2}{*}{ Cognitive Process 2} & Complete & 7 & \multirow{2}{*}{23.33} & \multirow{2}{*}{44.17} & 26 & \multirow{2}{*}{86.67} & \multirow{2}{*}{79.17} \\
\hline & Not Complete & 23 & & & 4 & & \\
\hline \multirow{2}{*}{ Psychomotor 1} & Complete & 6 & \multirow{2}{*}{20.00} & \multirow{2}{*}{32.50} & 25 & \multirow{2}{*}{83.33} & \multirow{2}{*}{75.50} \\
\hline & Not Complete & 24 & & & 5 & & \\
\hline \multirow{2}{*}{ Psychomotor 2} & Complete & 9 & \multirow{2}{*}{30.00} & \multirow{2}{*}{26.67} & 27 & \multirow{2}{*}{90.00} & \multirow{2}{*}{80.83} \\
\hline & Not Complete & 21 & & & 3 & & \\
\hline
\end{tabular}

Note: = Average grade, $\Sigma \mathrm{N}=$ Number of students.

Table 4 illustrates the learning outcomes of 30 students before learning for all tests, the percentage of completeness below $40 \%$. After four meetings the percentage of completeness is above $80 \%$. An increase in the completeness of the indicators in the six tests used. The improvement in this indicator's completeness is in line with the interventions used to practice scientific creativity. Activities on the student activity sheet with elements that support creativity are raised to expand the range of creative activities so that students can imagine and plan, implement, produce, find, compare, connect, find, (Dwikoranto et al., 2019). Furthermore, NGain results from pretest and posttest can be seen in the following Table 5. 
The Effectiveness of the Student Activity Sheet (SAS) on Teaching-Learning and Creativity (TLC) Model to Increase Creativity Competence

https://doi.org/10.46627/silet.v1i3.36

Table 5. Value of N-Gain and Sensitivity of Learning Outcomes Item

\begin{tabular}{|c|l|c|l|c|l|}
\hline \multirow{2}{*}{ No } & \multirow{2}{*}{ Learning Outcomes Test } & \multicolumn{2}{|c|}{ N-Gain } & \multicolumn{2}{c|}{ Sensitivity } \\
\cline { 3 - 6 } & & Coefficient & Information & Coefficient & Information \\
\hline 1 & Cognitive Products 1 & 0.93 & High & 0.46 & Sensitive \\
\hline 2 & Cognitive Products 2 & 0.82 & High & 0.60 & Sensitive \\
\hline 3 & Cognitive Process 1 & 0.74 & High & 0.62 & Sensitive \\
\hline 4 & Cognitive Process 2 & 0.63 & Medium & 0.34 & Sensitive \\
\hline 5 & Psychomotor 1 & 0.64 & Medium & 0.42 & Sensitive \\
\hline 6 & Psychomotor 2 & 0.85 & High & 0.56 & Sensitive \\
\hline
\end{tabular}

Table 6 states that the 4 test results of learning increased in the high category (cognitive product 1 , cognitive product 2 , cognitive process 1 , and psychomootor 2 ). Whereas the other 2 tests (cognitive process 2 and psychomotor 2) are in the moderate category and are still increasing. The use of Student Worksheets that accommodate a free, open, democratic, and positive learning atmosphere can enhance creativity (Hu et al., 2013, Suyidno et al, 2019).

\section{Student Responses to the Learning Process with student activity sheet model}

The response given by students at the end of the lecture by applying aspects of creativity in SAS and the tutorial model of Teaching Learning and Creativity results are as in Table 6 below.

Table 6. Results of Analysis of Student Responses

\begin{tabular}{|c|c|c|c|c|}
\hline \multirow{2}{*}{ Student Response Components } & \multicolumn{2}{|c|}{ Response Yes } & \multicolumn{2}{|c|}{ Response No } \\
\hline & Sum & $\%$ & Sum & $\%$ \\
\hline \multicolumn{5}{|l|}{ 1. Novelty of the learning process: } \\
\hline a. The way lecturers teach & 28 & 93.0 & 2 & 6.7 \\
\hline b. The language used is communicative & 27 & 90.0 & 3 & 10.0 \\
\hline c. The contents of SAS support creativity & 27 & 90.0 & 3 & 10.0 \\
\hline d. The atmosphere of independent learning & 29 & 96.7 & 1 & 3.3 \\
\hline \multicolumn{5}{|l|}{ 2. Clarity in conveying the creativity of the process: } \\
\hline a. $\quad$ Unusual use & 29 & 96.7 & 1 & 3.3 \\
\hline b. Problem finding & 29 & 96.7 & 1 & 3.3 \\
\hline c. Product improvement & 29 & 96.7 & 1 & 3.3 \\
\hline d. Scientific imagination & 29 & 96.7 & 1 & 3.3 \\
\hline e. Science problem solving & 29 & 96.7 & 1 & 3.3 \\
\hline $\begin{array}{ll}\text { f. } & \text { Science experiment }\end{array}$ & 29 & 96.7 & 1 & 3.3 \\
\hline g. $\quad$ Product design & 27 & 90.0 & 3 & 10.0 \\
\hline \multicolumn{5}{|l|}{ 3. Clarity in delivering product creativity } \\
\hline h. Unusual use & 29 & 96.7 & 1 & 3.3 \\
\hline i. $\quad$ Problem finding & 29 & 96.7 & 1 & 3.3 \\
\hline j. $\quad$ Product improvement & 25 & 83.3 & 5 & 16.7 \\
\hline k. Scientific imagination & 23 & 76.7 & 7 & 23.3 \\
\hline 1. $\quad$ Science problem solving & 23 & 76.7 & 7 & 23.3 \\
\hline m. Science experiment & 25 & 83.3 & 5 & 16.7 \\
\hline n. $\quad$ Product design & 24 & 80.0 & 6 & 20.0 \\
\hline \multicolumn{5}{|l|}{ 4. Clarity in the delivery of Psychomotor creativity } \\
\hline a. Psychomotor 1 & 24 & 80.0 & 6 & 20.0 \\
\hline b. Psychomotor 2 & 20 & 66.7 & 10 & 33.3 \\
\hline
\end{tabular}


Student responses to the implementation of learning for the novelty component of the learning process and the clarity of the delivery of creative processes are very favourable for the response component, the clarity of delivering positive product creativity (Dwikoranto et al., 2019). Overall the responses given by students were positive (Jamal, 2015).

\section{CONCLUSION}

Based on the results of research and discussion, it can be concluded that the SAS model of Teaching Learning and Creativity, which is applied to improve the competence of students' scientific creativity is effective. The conclusion above is based on the finding that the student activity sheet model developed to improve scientific creativity and student learning outcomes are effective. Because it increases students' scientific creativity after participating in learning significantly in the medium category and increases student learning outcomes after participating in learning in both categories and student responses to learning, they are positive.

\section{REFERENCES}

Astutik, S., \& Prahani, B. K. (2018). Developing teaching material for physics based on Collaborative Creativity Learning (CCL) model to improve scientific creativity of junior high school students. Jurnal Penelitian Fisika dan Aplikasinya, 8(2), 91-105. https://doi.org/10.26740/jpfa.v8n2.p91-105

Ayas, M. B., \& Sak, U. (2014). Objective measure of scientific creativity: Psychometric validity of the creative scientific ability test. Thinking Skills and Creativity, 13, 195-205.

Demir, S., \& Sahin, F. (2014). Assessment of prospective science teachers' metacognition and creativity perceptions and scientific toys in terms of scientific creativity. Procedia-Social and Behavioral Sciences, 152, 686 - 691.

Dwikoranto., Madlazim., \& Erman. (2019). Project based laboratory learning as an alternative learning model to improve sciences process skills and creativity of physics teacher candidate. Journal of Physics: Conference Series, 1387, 012074. https:// doi.org/10.1088/17426596/1387/1/012074

Dwikoranto, Munasir, Setiani, R., Suyidno, Surasmi, W.A., Tresnaningsih, S., \& Sambada, D. (2020). Effectiveness of project based laboratory learning to increase student's science process skills and creativity. Journal of Physics: Conference Series, 1491, 012006. https://doi.org/10.1088/1742-6596/1491/1/012006

Dwikoranto, Setiani, R., Madlazim, \& Erman. (2019). Validity of project based laboratory learning: an innovative physics laboratory learning to prepare sciences process skills and creativity of physics teacher candidate. International Conference and Technology, 1, 912-917. https://doi.org/10.2991/icst-18.2018.184

Dwikoranto, Surasmi, W. A, Suparto, A., Tresnaningsih, S., Sambada, D., Setyowati, T., Faqih, A., \& Setiani, R. (2018). Designing laboratory activities in elementary school oriented to scientific approach for teachers SD-Kreatif Bojonegoro. Journal of Physics: Conference Series, 997, 012041. https://doi.org/10.1088/1742-6596/997/1/012041

Eggen, P. D., \& Kauchak, D. P. (2013). Educational psychology: Windows on classrooms (9th edition). Pearson.

Fryer, M. (2012). Some key issues in creativity research and evaluation as seen from a psychological perspective. Creative Research Jurnal, 24(1), 21-28.

Gorghiu, G., Draghicescu, L. M., Cristea, S., Patrescu, M. \& Gorghiu, L. M. (2015). Problembased learning: An efficient learning strategy in the science lessons context. Procedia-Social and Behavioral Sciences, 191, 1865-1870.

Gregory, E., Hardiman, M., Yarmolinskaya, J., Rinne, L., \& Limb, C. (2013). Building creative thinking in the classroom: From research to practice. International Journal of Educational Research, 62, 43-50.

Gronlund, N. E. (1985). Measurement and evaluation in teaching (5th ed.). Macmillan. 
Hu, W., \& Adey, P. (2010). A scientific creativity test for secondary school students. International Journal of Science Education, 24(4), 389-403.

Hu, W., Wu, B., Jia, X., Yi, X., Duan, C. \& Meyer, W. (2013). Increasing student's scientific creativity: The "learn to think" intervention program. The Journal of Creative Behavior, 47(1), 3-21.

Jamal, A., \& Suyidno. (2015). Pemahaman kreativitas, keterampilan proses, dan sikap kreatif mahasiswa melalui pembelajaran kreatif pada matakuliah IPA dasar. Prosiding Seminar Nasional Tahun 2015, 1, 361-369.

Jewett, J. W., \& Serway, R. A. (2008). Physics for scientists and enginers (7th ed.). Cengage Learning.

Kellogg, L., Hurley, K., \& Kip, K. (2011). The partnership for 21st century Skills.

Liu., \& Lin. (2013). Primary teachers' beliefs about scientific creativity in the classroom context. International Journal of Science Education, 36(10), 1551-1567.

McCarty, C. (2010). Teaching for creativity: A study in reflective practice [Unpublised Doctor of Philosophy]. The University of Technology Sydney.

Moutinho, S., Torres, J. T., Fernandez, I., \& Vasconcelos, C. (2015). Problem-based learning and nature of science: A study with science teachers. Procedia-Social and Behavioral Sciences, 191, 1871- 1875.

Mueller, J. S., Melwani, S., \& Goncalo, J. A. (2012). The bias against creativity: Why people desire but reject creative ideas. Psychological Science, 23(1), 13-17.

Mukhopadhyay R., \& Sen, M. K. (2012). Investigation of creativity in physics in the context of learning in association with deep approach to study. Journal of Humanities and Social Science, $4(2), 24-30$.

Mukhopadhyay R., \& Sen, M. K. (2013). Scientific creativity-A new emerging field of research: Some considerations. International Journal of Education and Psychological Research, 2(1), 1-9.

Mukhopadhyay, R. (2013). Measurement of creativity in physics: A brief review on related tools. Journal of Humanities and Social Science, 6(5), 45-50.

Mukhopadhyay, R. (2014). Creativity in science education: Major concern of a science teacher. Conflux. Journal of Education, 1(9), 7-11.

Nur, M. (2014). Berpikir kreatif. Penelitian Unggulan Perguruan Tinggi: Universitas Negeri Surabaya.

Rahardjanto, A., Husamah, A., \& Fauzi, A. (2019). Hybrid-PjBL: Learning outcomes, creative thinking skills, and learning motivation of preservice teacher. International Journal of Instruction, 12(2), 179-192. https:// doi.org/10.29333/iji.2019.12212a

Rietzschel, E. F., Bernard, A. N., \& Wolfgang, S. (2010). The selection of creative ideas after individual idea generation: Choosing between creativity and impact. British Journal of Psychology, 101, 47-68.

Rotteram, K. (2014). Teaching, learning and creativity (TLC) model for science. SSR, 95, 79-84.

Santrock. (2009). Educational psychology. John Wiley \& Sons, Inc

Sudarma, M. (2012). Mengembangkan keterampilan berpikir kreatif. Rajawali Press.

Sugiyono. (2010). Metode Penelitian Pendidikan Pendekatan Kuantitatif, kualitatif, dan RED. Alfabeta

Suyidno, \& Nur, M. (2015). Pemahaman kreativitas ilmiah mahasiswa dalam pembelajaran kreatif pada matakuliah IPA dasar. Prosiding Seminar Nasional Tahun 2015, 1, 1361-1366.

Suyidno., Nur, M., Yuanita, L., Prahani, B. K., \& Jatmiko, B. (2018). Effectiveness of creative responsibility based teaching model on basic physics learning to increase student's scientific creativity and responsibility. Journal Baltic Science of Education, 17(1), 136-151.

Suyidno, Susilowati, E., Afiruddin, M., Misbah, Sunarti, T., \& Dwikoranto. (2019). Increasing students' responsibility and scientific creativity through creative responsibility based learning. Jurnal Penelitian Fisika dan Aplikasinya, 09(02), 178-188. 
Torrance, E. P. (2013). Scientific views of creativity and factors affecting its growth. Daedalus, 94(3), 663-681.

Tri, H, (2011). Langkah-langkah mudah melakukan analisis statistik. Menggunakan SPSS 20. CV ANDI OFFSET

Wibowo, F. C., \& Suhandi, A. (2013). Penerapan model Science Creative Learning (SCL) IPA berbasis proyek untuk meningkatkan hasil belajar kognitif dan keterampilan berpikir kreatif. Jurnal Pendidikan IPA Indonesia, 2(1), 67-75.

\section{Author (s):}

* Dwikoranto (Corresponding Author)

Department of Physics, Faculty of Mathematics and Natural Science,

Universitas Negeri Surabaya,

Jl. Ketintang, Surabaya 60231, Jawa Timur, Indonesia

Email: dwikoranto@unesa.ac.id

\section{Rahyu Setiani}

Bhinneka PGRI University of Tulungagung,

Jl. Mayor Sujadi Timur No.7, Ploso Kandang, Tulungagung 66221, Jawa Timur, Indonesia

Email: rahyusetiani@gmail.com

Barokah Widuroyekti

UPBJJ-UT Semarang,

Jl. Pantura Semarang - Kendal No.KM. 14, Mangkang Wetan, Kec. Tugu,

Kota Semarang 50154, Jawa Tengah, Indonesia

Email:barokaw@ecampus.ut.ac.id

Sri Tresnaningsih

UPBJJ-UT Surabaya, Campus C Mulyorejo Unair 60115, Jawa Timur, Indonesia

Open University, Indonesia

Email: sritresnaningsih@ecampus.ut.ac.id

Dwi Sambada

UPBJJ-UT Surabaya, Campus C Mulyorejo Unair 60115, Jawa Timur, Indonesia

Open University, Indonesia

Email: dwisambada@ecampus.ut.ac.id

Titik Setyowati

UPBJJ-UT Surabaya, Campus C Mulyorejo Unair 60115, Jawa Timur, Indonesia

Open University, Indonesia

Email: titiktyowati@ecampus.ut.ac.id

Agus Rohman

STKIP Al Hikmah Surabaya, Indonesia

Jl. Kebonsari Elveka V, Kebonsari, Kec. Jambangan, Kota SBY, Jawa Timur 60232, Indonesia

Email: agus.rohman5ure@gmail.com

Basuki Tri Harnoto

SMAN 1 Krembung Sidoarjo, Jawa Timur, Indonesia

Email: triharnotobasuki8@gmail.com 